\section{Initiative waives human life in favour of life on humans}

Microbe experts from around the world are setting up a formal collaboration to study the organisms that live in and on humans.

The International Human Microbiome Consortium, announced on 16 October, involves geneticists and bacteriologists from more than a dozen countries. The researchers will look at the role of the microbiome - the microorganisms that dwell in and on the body and that vastly outnumber the body's own cells - in health and disease.

The consortium's two most prominent projects are a five-year initiative funded by the US National Institutes of Health (NIH) to genetically sequence microbes living in the mouth, skin, nose, vagina and faeces; and a four-year, European Commission scheme to analyse the gut flora of people living in Spain and Denmark to find microbial links to obesity and inflammatory bowel disease.

The NIH has pledged US\$115 million to the overall initiative and European collaborators have committed $€ 20$ million (US\$27 million). Other countries will provide smaller sums.

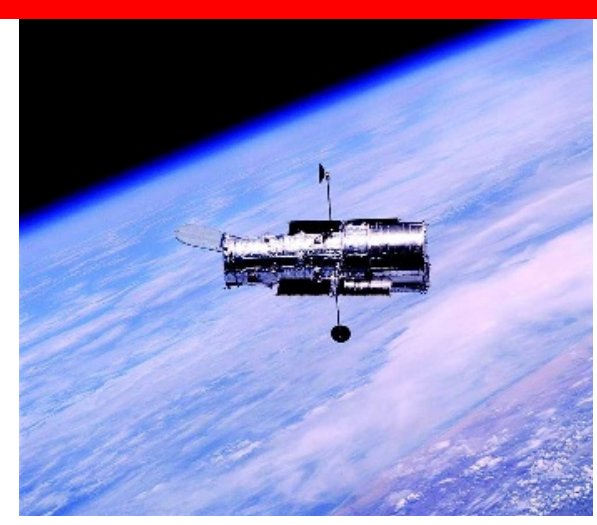

Hubble: currently comatose.

\section{Computer failure leaves Hubble in limbo}

Late last month, the main system for storing and transmitting data from the Hubble Telescope's science instruments failed. Operators can still send commands to the 18-year-old orbiting observatory, but they can no longer retrieve the images that have made it famous.

On 16 October, telescope engineers successfully booted up a backup for the faulty system. But as they were preparing to resume star-gazing, problems with the backup computer sent the entire spacecraft into safe-mode. NASA officials hope that Hubble will be healthy again by the end of this week, but are not certain when it will be back in action. A shuttle mission to service the telescope has been delayed until at least February so that engineers can develop fixes for the computer problems.

\section{US agencies struggle over public relations}

It is report-card season for US science agencies, and the grades are in on their media skills. The Union of Concerned Scientists, an advocacy group based in Cambridge, Massachusetts, has ranked the public-relations policies of 15 federal organizations.

It gave the highest marks to the Centers for Disease Control and Prevention in Atlanta, Georgia, whose written policy allows scientists to express their personal views. NASA also fared well, earning a " $B$ " for its policy and a "satisfactory" for its practice. The Environmental Protection Agency (EPA) finished near the bottom of the class - its lack of an agency-wide policy earning it a " $D$ ".

The group says that the grades will help the next president to reduce the censorship of government scientists, but EPA spokesman Jonathan Schradar called the grades "nothing more than continued petty politics". 